\title{
TAX EVASION AND MODELLING
}

\section{LE TRUNG KIEN}

PhD in Law, Head of the postgraduate department, People's police Academy, Hanoi, Vietnam

\begin{abstract}
Each country implements its own tax system. Systemic analysis of tax burden, severity of taxation is a pressing problem not only socio-economic, but also legal. This is facilitated by the often observed tax evasion of the taxpayer, the concealment of his income. Effective investigation of tax offences requires the involvement not only of tax laws, IT, but also of mathematical, computer modeling of the taxpayer's behavior, his choice. This problem is relevant in many countries, especially developing countries. In Vietnam, as in Russia, this problem is studied quite carefully and methodologically correctly. In addition to system-wide modelling principles, flexible, problem-oriented models of different tax situations and regional or sectorial taxes are also explored. In this work, a systematic analysis of the problem of the severity of the tax burden was carried out and an expandable model of tax evasion was proposed. The model proposed in the work is intended for the initial stage of modeling, so the conclusion indicates possible ways to modify them. It's a complex and multidimensional task, it's necessary to solve it iteratively, gradually reducing uncertainty and structural complexity of the system. The system analysis performed will allow implementing adaptive simulation procedures with adequacy estimates on each iteration and model improvement. The model version considered takes into account tax evasion as a function of increasing the tax burden and other functions. A comparison was made with the classical Laffer curve. Based on the analysis of models of taxation and tax regulation, the work discusses various modifications of the proposed model of tax evasion. Not only socio-economic aspects of tax burden optimization are considered, but also legal, social, technological. The behavioral principles of the taxpayer and the tax inspector, their interactions in the calculation, control and payment of taxes are taken into account. Situational modelling of such interactions will facilitate and facilitate such interactions for the benefit of the State and society.

KEYWORDS: Taxes, Concealment, Payment, Taxpayer, Tax system, Analysis, Modeling \& Forecasting
\end{abstract}

Received: Jun 01, 2020; Accepted: Jun 20, 2020; Published: Jul 03, 2020; Paper Id.: IJMPERDJUN2020182

\section{INTRODUCTION}

The task of filling the budget in any country is a responsible task. It's decided according to the adopted system of taxation, taking into account its gravity for taxpayers. Taxpayers either pay tax fees neatly or do not want to "give their money". This also applies to legal entities, commercial and business structures. Everyone is trying to "save", reduce taxes. So-called legal tax optimization is particularly popular. There is also an extreme, risky and illegal manifestation of "optimization" or the taxpayer's departure into shadow circulation. Everyone tries to reduce taxes by properly optimizing their structure, using imperfections and ambiguity of tax norms and laws. For example, by modeling revenues and predicting tax expenses, taking advantage of tax incentives, losing the situational behavior of the tax inspector [1]. Therefore, it's important to be able to model the behavior of the taxpayer, predict revenues to the budget and its possible losses due to non-payment of taxes. Only on this basis can automated tax systems be implemented.

The most important functions of the state for the budget are social, fiscal, regulatory, distributive, control 
and stimulating functions. For each of them tax control is carried out, scheduled tax checks are carried out. They are expensive and time-consuming, often long-lasting. Therefore, taxpayers should be motivated and "forced" to pay taxes fully, using both monitoring data, forecasting results and legal laws.

In the tax system of Viet Nam, there are contradictions between a number of its provisions and the interests of the State, legal entities and the population. They often lead to conflicts, so in order to form (change) the tax system, it's necessary to take into account all different interests, highlighting the main interest - budget.

It's relevant to explore the economic interests of participants in fiscal relations in such a way that they resolve emerging contradictions and conflicts. This is only possible with a system approach using mathematical and computer modeling [2]. Key factors for managing the system should be identified and their parameters adequately identified. This will allow carrying out situational modeling by tax systems, to implement different scenarios of tax burden and different economic interests of participants [3]. Therefore, such modeling will increase the inflow to the budget, reduce non-payment and concealment from taxes, as well as reduce the dissatisfaction of taxpayers.

In this work, a systematic analysis of problems of tax evasion, various models for modeling the severity of tax burden and instruments implementing tax fees has been carried out.

In this work, a systematic analysis of problems of tax evasion, various models for modeling the severity of tax burden and instruments implementing tax fees has been carried out. Based on the system analysis of models of severity of tax burden and solution of problems of tax regulation and control, the work considered the model of behavior of the taxpayer evading taxes, discussed its various modifications, and indicated evolutionary directions for their development.

\section{Theoretical Framework}

Classically the severity of taxes is accepted to evaluate and display the parabolic curve A.Laffer [4, 5]. According to this line, the reduction of taxes on business and entrepreneurship under certain conditions can intensify their investment activities [6]. But now it's common to associate the reduction of tax revenues with the increase of taxes [7] with the transition of the enterprise to the shadow economy (perhaps partially). Laffer's concept is discussed and considered not entirely relevant to the modern theory of fiscal regulation [8]. But it's used to train tax burden models in theoretical (macroeconomic) modelling of fiscal $[9,10]$.

Research into the impact of taxes on the digital economy is a pressing issue that requires information and logic analytics and a situational approach. The tax rate is lower, which is lower than on the Laffer curve stimulates the taxpayer's business, but can deepen the contradictions of budget revenues. The digital economy is designed to free investment from unnecessary links that interfere with the investor.

The fiscal function of the macroeconomic level is additive to the functions of enterprises. It depends on demand, price, costs, volume of production, average rate, lower limit of profitability values, etc. With its simplicity, such a model allows you to investigate the impact of taxes on the economic condition of an enterprise.

The contradictions between the tax interests of the state, business and citizens are due to the insufficient level of tax culture. The coercive nature of taxes also affects the prevalence of fiscal function in their relations. Everyone solves their optimization task, with different target functions, interests and methods.

Taxpayers need a low level of tax burden. If it's not low enough, as well as accompanied by weak social support 
and state benefits, the taxpayer seeks to reduce tax payments. The State should respond to this by introducing new taxes, increasing rates. So there is the problem of tax evasion and the need to strengthen the fiscal component.

Unduly high tax rates are fraught with social explosion. A new public contract should be adopted urgently, where the following will be regulated:

- categories and tax rates of individuals and legal entities, entrepreneurs;

- the ability of a person to pay taxes, for example, on his total income, but taking into account the subsistence minimum and social structure;

- economic basis, justification of taxes and social tax incentives;

- differentiation of tax burden;

- impact of taxes on production (by industry), investment, and innovation;

- complex accounting and tax reporting procedures;

- the same tax rights of all payers.

Contradictions of interest in tax relations, such as the need to pay exorbitant taxes, lead to evasion. The high tax burden is justified only with a large social component of the state fiscal policy. This in Vietnam has not been sufficiently worked out, sometimes the principles of fair competition and efficient spending of taxpayers "funds, public finances have been violated. Both horizontally and vertically, taking into account the principle of fairness, timeliness and transparency of results in relation to all categories of taxpayers.

Tax types are taken into account (Table 1 shows, for example, the main taxes in the Russian Federation).

Table 1: Main Taxes of the Russian Federation and their Dynamics for 2012-2016 (million rubles)

\begin{tabular}{|l|c|c|c|c|c|}
\hline \multirow{2}{*}{\multicolumn{1}{|c|}{ Types of Tax }} & \multicolumn{5}{c|}{ Years } \\
\cline { 2 - 6 } & $\mathbf{2 0 1 2}$ & $\mathbf{2 0 1 3}$ & $\mathbf{2 0 1 4}$ & $\mathbf{2 0 1 5}$ & $\mathbf{2 0 1 6}$ \\
\hline NDFL, including: & 7060.20 & 9083.06 & 10402.10 & 11018.20 & 12130.40 \\
\hline dividend tax & 58.00 & 69.80 & 82.09 & 71.02 & 50.32 \\
\hline from nonresidents & 4.10 & 3.89 & 4.00 & 3.90 & 4.20 \\
\hline from prizes & 8.20 & 8.90 & 10.00 & 10.70 & 11.00 \\
\hline Personal income tax of businessmen & 23.50 & 35.67 & 44.80 & 62.00 & 69.70 \\
\hline Tax base & 2592.63 & 8631.00 & 15141.18 & 40098.76 & 49423.64 \\
\hline
\end{tabular}

The complexity of analysis and research of state budget tax risks is related to the complexity of variables and the influence of subjective and external factors. They are higher than microeconomic risk factors for organizations, businesses. The State should take into account the structural interests of the subjects of legal relations and the complexity of their relations. Creating mechanisms, procedures to identify, assess and adaptively manage risks in a timely manner is a pressing task.

\section{METHODOLOGY}

There are various categories and models of behavior, tax control, interaction between taxpayers and tax authorities, etc. More model-related categories. The work [11] notes the existence of at least six values of the definition of "pattern of conduct" applicable to tax systems. In particular, it's noted that the model of behavior of taxpayers (and tax inspector) - the official type, depends on the specificity of subjects of legal relations and the specific environment of tax relations. In the group of factors affecting the behavior of the taxpayer, we can note the transition to the understanding of taxation as a subsystem of 
the society's strategy. Factors such as currency volatility, geopolitical, excessive regulation, increased tax burden, capital availability, social instability, etc.

The fact of imperfections of the tax legislation of Vietnam is recognized by many scientists. Taxpayers seek to optimize, at least, legally tax charges and payments, and tax authorities, at least, to optimize their collecting.

The principle of tax fairness is not always consistent with the principle of voluntary payment. In practice, there are non-payments due to negative expectations and mistrust of the state. For example, in Russia, only 182 residents and 68 nonresidents used the new tax norm (independent notification of tax authorities) during the year.

The taxpayer's pattern of behavior is influenced by both the market and the legal system. Risk management is used to reduce tax checks, in the absence of sufficient justification, information about potential tax offences, etc. Risk assessment is used to manage them for all groups of taxpayers [12]. The methodology of leading scientists considers the method of tax control to be part of the legal regulation of public relations.

In order to minimize the risk of tax evasion, it's important to create comfortable conditions for the registration of taxpayers, automated accounting and control, and relevant legal regulation. It's necessary to build up analytical potential and models of analysis and forecast of tax violations, tax monitoring. Tax monitoring is a preventive tool for tax control. It removes uncertainty, allows developing effective models of taxation, and allows developing models of non-linear dynamics [13]. Mathematical and computer models of the relationship of high tax rates and production growth, welfare of the population and deductions to the budget are needed [14]. Russia's digital economy under construction will also update modeling problems $[15,16]$.

\section{RESULTS AND DISCUSSIONS}

Consider a situation that is determined using the following simulation hypotheses. The taxpayer receives random income, but tries, as much as possible, to evade taxes by declaring income less than actually received. The inspector tries to identify this attempt, but in a stochastic environment, with random conditions. The offender will pay all shortcomings and fines if he is caught. Tax scrutiny involves costs, although the tax authority seeks to maximize tax charges and minimize costs. The Inspector has the necessary information and determines the probability of another inspection.

So, the model situation has two outcomes:

- low income A (taxes are not paid with some probability);

- with high income B (taxes are paid with some probability).

The taxpayer wants to declare income below real, but the inspector checks such taxpayers with some probability. If evasion is established, the taxpayer is subject to a fine in the amount of $\mathrm{F}$. The fine is included in the unpaid tax, deficiency. The cost of inspection by the inspector is $\mathrm{s}$.

The challenge: to find the probability of p checking a taxpayer who declared low returns if it's necessary to maximize $\mathrm{R}$ tax charges without taking into account the costs of checking.

The situation is playful, the behavior of the taxpayer - according to the strategy of achieving high income, taking into account both events A, B. Maximize the income of honest A-B and dishonest behavior (tax evasion) - the amount of $B-p F$. If $\mathrm{T}$ is taxable income, the probability of verification does not exceed the $\mathrm{T} / \mathrm{F}$ ratio. It's a reflection of high-income 
taxpayer evasion. Tax income against the taxpayer is identified by the ratio:

$$
R(p)=p(q F-c)
$$

If the probability of verification is greater than $\mathrm{T} / \mathrm{F}$, there is no evasion, so tax income will be: $R(p)=q T-$ $p(1-q) c$

The T/F limit value defines the probability of "fair behavior" in the interval $(0 ; \mathrm{T} / \mathrm{F})$ where violations can be detected.

It is possible to test the case of probability of checking $\mathrm{p}$ and revenues of budget $\mathrm{R}$ on test numerical examples. For example, to hide revenues, increase fines and increase the cost of verification. Test examples $(\mathrm{T}=10-20, \mathrm{~A}=20-30, \mathrm{~B}=40$ $50, \mathrm{~F}=40-50, \mathrm{q}=0.4-0.5, \mathrm{c}=10-15, \mathrm{p}=0.2-0.3)$ conclude:

- $\quad$ the penalty reduces the T/F limit of the verification probability ("taxpayer's limit honesty");

- the frequency of inspections reduces heavily revenues to the budget, increasing the jump in revenues;

- to increase a little probability of checks is not scary, without underestimating their level (otherwise an honest taxpayer can change behavior by feeling "easy revenues" and impunity);

- increasing the frequency of inspections can increase fees, including fines (according to the probability, the majority of taxpayers will consider that it benefits to pay fair taxes);

- if the fine increases, the number of payers and tax income increases.

A legal model of punishment under the tax law should be attached to the model. As well as the economic model of the taxpayer's economic development. Development will naturally increase future revenues to the budget (provided that the first model task is correctly solved).

As an economic balance model, consider the dynamic relationship of species:

$$
p(t)=q(s(t)-z(t)) k i(s)
$$

This ratio involves $\mathrm{p}(\mathrm{t})$ - the taxpayer's profit at time $\mathrm{t}, \mathrm{q}$ - the value of his product at the initial $(\mathrm{t}=0)$ time, $\mathrm{s}(\mathrm{t})$ the price premium of the cost of production, $\mathrm{z}(\mathrm{t})$ - the constant cost in cost, $\mathrm{i}(\mathrm{s})$ - the tax "saved" by the taxpayer (more precisely, their share k).

Then all taxes will be paid

$N(T)=\operatorname{alp}(t)(q s(t) i(s(t-1))$,

where 1 is the tax evasion factor; $\mathrm{A}$ is the tax rate.

Situational modeling allows different sets of parameters (bets) to be considered, as in the classical Laffer model. You only need to specify $\mathrm{p}>0$.

The model can be developed further, complicating hypotheses (nature of situations) and structure, complexity of connected models. In the initial stages, the proposed model is useful for strategy development, training and accumulation of analytical information, which often plays a decisive role [17]. 
Profit $\mathrm{p}$ can also be described as an optimization task:

$P=\min (c F, Q)-E-F$

where $\mathrm{c}$ is the unit cost of the product (one product production), $\mathrm{Q}$ is the demand for the product, $\mathrm{T}$ is taxes, $\mathrm{E}$ is the total cost of the manufacturer.

If you model the effect of the two main taxes (for example, on profit and property), you can modify the profit model as

$$
P(T)=(1-a)(Y(t)-W(t)-d K(t-1)-h K(t))
$$

where $\mathrm{a}$ is the income tax rate, $\mathrm{h}$ is the property tax rate; $\mathrm{D}$ is the depreciation rate for the year; $\mathrm{Y}$ - value added per year; W - remuneration (with accruals); $\mathrm{K}$ - fixed capital at the end of the year t; P - profit (net, after taxes).

It's interesting to connect a model of the evolution of the tax system, for example, through regression dependencies, as well as corruption [18]. A separate problem is the problem of corruption and organized tax crimes with accompanying tax evasion [19].

The integrated model should identify optimal modes of operation and payment of taxes, risk and profit management. Profit generation depends on fund turnover and investment efficiency.

Taxes spur the taxpayer to rise, though they reduce its finances. Dynamic work and payment of taxes are stimulated. Tax provides benefits that create prerequisites for accumulation of financial reserves, liberalization and revival of taxpayer activity.

According to the theory of welfare, the payment of tax should not impair the well-being of the taxpayer before taxation or contrast it to the counter-benefits of the state. After the payment of taxes, the set of consumer goods only changes. If the taxes paid were equivalent to the benefits of consuming public goods, there would be no tax burden. In fact, well-being can fall only because of the replacement of taxable products by those that are taxed at low rates or are not taxed at all.

Models of optimal taxation should offer values that guarantee a given level of tax revenues to budgets with minimal risks of taxpayer efficiency. For this purpose it's necessary to have a complex of imitation [20], effectively played situations and models of taxation of different types ("hard", "moderate" or "light ").

\section{CONCLUSIONS}

Tax administration is a complex and multi-criteria process. There are also accidents as well as uncertainties affecting outcomes. It's important to model the severity of the tax burden and predict the sustainability of tax collection. The functions involved in models, for example, the demand function is assumed to be usually linear, but evolutionary economics requires nonlinear models that are complex and relevant to that economy.

It's important to take into account the tax burden, the sustainability of tax fees. Efficient and flexible (and therefore simple) integral models, identification algorithms are needed.

This work proposes such models and indicates their further development in order to identify the described situation with accuracy to the parameters involved in the model description. The present study can be further developed, for example, by taking into account the available resources of the taxpayer, the redistribution of profits and an effective tax system. 


\section{REFERENCES}

1. Levin, M.I., Levina, E.A, Pocatovich, E.V. (2011) Lectures on corruption economics. -M.: Higher School of Economics National Research University.

2. Kaziev, V.M. (2007) Introduction to analysis, synthesis and modeling of systems. Laboratory of knowledge. - 244 p. ISBN 594774-511-9 URL: https://www.intuit.ru/studies/courses/83/83/info (date of the address: 20.04.2020).

3. Grigorieva, K.S. (2012) Contradictions of interest and conflicts in the system of tax relations // Journal of Tomsk State University. Economy. N1(17), -pp.109-112.

4. Laffer, A. (2018) The Laffer curve: Past, Present, and Future [Electronic resource]. - Retrieved from: https://www.heritage.org/taxes/report/the-laffer-curve-past-present-and-future/ (date of the address: 25.04.2020).

5. Trabandt, M., Uhlig H. (2011) The Laffer Curve Revisited // Journal of Monetary Economics. 2011. Vol. 58. -pp.305-327.

6. Gusakov, S.V., Jacques S.V. (1995) Optimal equilibrium prices and Laffer point // Economics and mathematical methods. Vol.31. Iss.4. - pp. 346-358.

7. Gubar, E.A., Zhitkova, E.M., Kumacheva, S.S., Tomilina, G.A. (2019) Modeling of processes of impact of information on checks on risk-statuses and tax evasion // Journal of St. Petersburg University ("Applied Mathematics. Informatics. Management processes"). Vol.15. Iss.2. -pp. 245-258. https://doi.org/10.21638/11702/spbu10.2019.208.

8. Balatski, E.V. (2004) Assessment of the impact of fiscal instruments on economic growth // Forecasting problems. N4. -pp.124135.

9. Borsi, I., Primicerio, M. (2014) Mathematical models for social and economic dynamics and for tax evasion: a summary of recent results // Vietnam Journal of Mathematical Applications. V.12, I.3.

10. Cremer, H., Gahvari, F. (1993) Tax evasion and optimal commodity taxation // Journal of Public Economics. - I. 50. - pp.261275.

11. Advokatova, A.S. (2017) Relationship between taxpayer behavior and tax control // Taxes and taxation. N5. -pp.149-157.

12. Pechenegina, T.A. (2016) Tax risks: minimization and prevention of their negative consequences // MIR (Modernization. Innovations. Development). Vol.7. N4. -pp.53-58. DOI: 10.18184/2079-4665.2016.7.4.53.58

13. Economics and Management in the Conditions of Nonlinear Dynamics (2017) / Under the editorship of Doctor of Economics, Professor A.V. Babkin. St. Petersburg, Publishing of Polytechnic University. -773 p.

14. Lebedev, V.V., Lebedev, K.V., Tyupikova, T.V. (2018). Computer simulation of taxation//University Gazette. № 12. -pp.129-134. DOI 10.26425/1816-4277-2018-12-128-135.

15. Kirov, E.A., Morozova, N.G., Besverhii, A.S. (2019) Transformation of the tax system of Russia in the conditions of the digital economy // University Gazette. N7. DOI 10.26425/1816-4277-2019-7-118-124

16. Yukhnevich, E. (2018) New Limits on Tax Regulation in Light of Taxation of Electronic Commerce // Enforcement. Vol.2, $N 4$. -pp. 51-59. DOI 10.24147/2542-1514.2018.2(4).51-59.

17. Aganbegyan, A.G. (2017) On tax reform//Economic policy. Vol.12. N1. -pp.114-133 DOI: 10.18288/1994-5124-2017-1-05.

18. Chander, P, Wilde, L. (1992) Corruption in Tax Administration // Journal of Public Economics. Vol.49. №3. -pp.333-349.

19. Sidorov, V., Baleev, S. (2019). Criminal group and group methodology for the commission of an offence in Russian criminal law. Amazonia Investiga, 8(18), -pp. 330-336. Retrived from: 
https://www.amazoniainvestiga.info/index.php/amazonia/article/view/315 (date of the address: 26.04.2020).

20. Antoci, A., Russu, P., Zarri, L. (2014) Tax evasion in a behaviorally heterogeneous society: An evolutionary analysis // Economic Modelling. Vol.10, N42. -pp.106-115.

21. Masih, J., \& Nim, D. Trend Forecasting Of Twitter Followers For Plan International.

22. Pribadi, S. R. W., \& Pribadi, T. W. The Implementation Of Tourism Demand Forecasting Using Seasonal Arima For The Investment Analysis Of Floating Aquaculture.

23. Sultan, J. A., \& Jasim, R. M. (2016). Demand forecasting using artificial neural networks optimized by artificial bee colony. Int J. Manage, Inf. Technol. Eng, 4(7), 77-88.

24. Ramakrishna, G., \& Kumari, R. V. (2018). Arima Model for Forecasting of Rice Production in India by Using Sas. Siam J. Appl. Math, 6, 67-72. 